\title{
YOUR FACE
}

The price of success.

\section{BY GRACE TANG}

"W elcome home, Mendel." I greeted my DNA Scraper unit as it returned home for the day with its finds. I realized I was talking to my robots - probably a consequence of spending the past year living and working alone.

I picked Mendel up from the ground, popped its lid open, and dumped the contents of the sample compartment into the desktop gene-sequencing apparatus. Cigarette butts, small vials of excrement scrapings, more needles than I could count ... The city ought to be paying me at the rate Mendel was cleaning up the homeless encampments for them.

I microwaved yesterday's leftovers while the analysis ran. For more than a year since I'd quit the force, this had been my daily routine. Too hungry and impatient to wait for the first dish to be ready, I grabbed another box straight from the fridge and ate the contents cold. I sighed. I just needed to be patient till I hit the jackpot.

The microwave's beeping sounded off - I was wondering if it had received a software update when I realized the unfamiliar chime was in fact coming from the gene sequencer. Slightly concerned, I went to investigate, wondering if the warranty was still valid.

I nearly choked on my cold day-old mushu pork.

For the first time since I'd acquired this unit, its screen displayed a face - your face, or at least the best guess the algorithm had generated, based on the DNA extracted from one of Mendel's samples. You were a match.

The algorithm tweaked the features of the 3D model as its confidence in aspects of your appearance grew.

You were of majority Caucasian descent, with a wide, flat nose, thin lips and brown hair (the 95\% confidence interval was between dirty blonde and deep chestnut). Telomeric analysis placed your biological age at around 40 .

But what caught my attention were your eyes - amber, fading to green around the

ONATURE.COM Follow Futures: @ @NatureFutures

f go.nature.com/mtoodm edges ( $96 \%$ confidence), staring back at me from the screen.

Once upon a time, the world had had a diversity of eye colours. Blue, green, violet, you name it. But over time, as the people of the world overcame the barriers that separated them, genes intermixed, and dominant genes turned the globe's eyes into a monotonous shade of brown, rendering any other eye colours a rarity.

found you slumped in an alley, drifting in and out of consciousness, surrounded by used needles and puddles of piss and vomit. Your frazzled hair stuck out of your head like an unkempt jungle, and your cheekbones jutted out of your malnourished face, but otherwise, you were a spitting image of the face that had stared at me from my computer back home. Your arms were covered in sores. Perhaps it was better, what they were going to do to you.

I held my nose with one hand to block the stench of old urine and puke, and swabbed you with my other hand - you barely noticed. I ran your sample through my portable kit.

The green light confirmed a match to the DNA from the needle. Somewhat reluctantly, I called the number.

It was all happening so fast. An ambulance rolled down the alley and pulled up beside us.

“This him?" The 'paramedic' asked. I nodded.

He grinned wordlessly — tonight we would both be eating well. I caught a glimpse of your green eyes as they loaded you on a stretcher and put you in the back of the ambulance.

Somewhere, today, our client would be jumping several spots up

To have two recessive genes for light eyes, you must have been something special. I thought of the royal family and their equally purebred corgis. Maybe you were royalty...

But probably not. Your sample had come from a needle.

Punching in instructions to analyse the non-genetic material in your sample, I confirmed the presence of heroin. Thankfully, the tests for HIV, and hepatitis B and C came out negative, otherwise my client would not have been pleased. I hoped you were still alive.

The next day, I dusted off Argos, a much more sophisticated Seeker model. I inserted an amplified vial of your DNA and synced the results of the predictive algorithm with the coordinates of where your first sample was found, then set Argos off into the world.

I had waited more than a year for Mendel to find a sample with sufficient genetic overlap with one of my clients, but it wasn't even a full day before Argos found you. I guess addicts did not travel far from the things they left behind. I had not expected mylongawaited triumph to be laced with regret.

I set out to the coordinates Argos sent, and to the top of the organ-donation waiting list, because, miraculously, a close genetic match had been found (totally without the help of a retired inspector using self-refurbished police equipment smuggled from the forgotten depths of the electronics-recycling centre). Fortuitously, the donor had died of an overdose before the ambulance could get him to the hospital (despite the best efforts of the paramedics, who absolutely did not inject him with even more of the substance that was killing him).

No one would miss one more nameless addict off the streets.

That night, I received the password to an untraceable wallet containing more money than I had ever seen in one place. If you had asked me a year ago what I thought I'd feel when I finally completed this assignment, I would not have guessed that it would feel like this. I ordered my first decent dinner in a year, powered down Mendel and Argos, and tried to forget your face.

After obtaining a PhD in psychology from Stanford University, Grace Tang now works as a data scientist in the tech industry. 